\title{
Erratum zu: Survey-Welten
}

\section{Erratum zu: \\ R. Vogel, Survey-Welten, Soziologie der Konventionen, https://doi.org/10.1007/978-3-658-25437-7}

Dieses Buch wurde vormals ohne Hinweis auf die Fördergesellschaft und Zuschußgewährung publiziert. Der Fördervermerk wurde in der aktuellen Version ergänzt und ist auf der Impressumsseite des Buches zu finden.

Die aktualisierte Version des Buches finden Sie unter https://doi.org/10.1007/978-3-658-25437-7 